\title{
Flavius Mauricius - Glimpses into the Life and Career of Roman Military Official
}

\author{
Jiří Honzl
}

(Charles University in Prague)

\begin{abstract}
A small collection of textual evidence, two papyri, three inscriptions, and three literary testimonia, is brought together and examined. All these pieces of evidence possibly mention the same person, a high military official Flavius Mauricius of the fourth century CE. The individual pieces of written evidence are at first considered separately in their context, with the focus put on particularities possibly significant for the current study. In the next step they are all evaluated for the likelihood of being in fact related to one another. As a consequence, they are sorted into groups of 'core' evidence, almost certainly belonging together, and 'peripheral' evidence only possibly related to the rest. Finally, the available evidence is analysed and considered in the context in order to allow at least a partial reconstruction of the background, career, and other bits and pieces of the life of Flavius Mauricius. The best and most certainly documented part of his career is the period of service in the capacity of dux Aegypti, a military commander of the province, which took place no earlier than 368 CE and continued at least until 375 CE and maybe later. Other less certain pieces of evidence possibly allow to also get a glimpse into other stages of Mauricius's life, as he may have taken part in the Persian campaign of emperor Julian and could have been buried in the Macedonian city of Philippi. Quite remarkably, all the contemporary pieces of evidence were written in Latin, either entirely or in combination with Greek. Thus, it is considered separately, what the reasons for the choice of this language were and whether it was a result of Mauricius's personal preference. Overall, like many of his fourth century contemporaries, Flavius Mauricius appears throughout his life to have his identity rooted in the Roman tradition, while concomitantly he was able to embrace some of the ongoing changes in society.
\end{abstract}

\section{Keywords}

Egypt; Late Antiquity; Roman army; Flavius Mauricius; military career; dux; Latin language

The paper was written within the framework of the project 'Continuity, Discontinuity and Change. Adaptation Strategies of Individuals and Communities in Egypt at Times of Internal and External Transformations' supported by the Czech Science Foundation (grant no. 19-07268S). The author would like to express his gratitude to Daniela Urbanová and Filip Coppens for their suggestions, comments, and corrections, and to Ulrike Ehmig, and Rudolf Haensch for valuable consultations. 


\section{Introduction}

Beginning with the ground-breaking discoveries made around the 1900, the enormous amount of textual evidence of Ptolemaic to Late Antique date became notorious. These texts include not only papyri, which are the most numerous, but also ostraca, wooden tablets, parchments, and inscriptions on stone and other materials. Found largely disarranged, scattered, and for the most part preserved by chance, considering their absolute volume, they rarely yielded sets of closely related texts, pertaining to a single person, family, group or institution. While some of the largest and most famous archives, like those of Zenon, Dioskoros, or Heroninos (Broux 2019: pp. 401-403; Vandorpe 2019: pp. 273-276), comprise a considerable volume of papyri, a large majority of others contain several dozens of texts at best. Apart from Greek, Demotic and Coptic records, such archives contain also texts written in languages that were rather rare in Egypt, including Latin. The occurrence of Latin in these collections is scarce. Virtually only with the exception of the letter archive of Claudius Tiberianus (inter alia Adams 2003: pp. 593-596), Latin documents never constituted a predominant let alone major part of them. It is even rarer to be able to identify closely related texts recovered from unrelated contexts, containing very different textual genres, and preserved on various media. All such collections of texts are essential for the understanding of various aspects of the past Egyptian societies. In fact, they allow to consider the texts included not only as isolated occurrences, but as parts forming larger and inherently more meaningful units.

The current paper explores a small collection of five contemporary texts and three literary testimonies all of which are proposed, with various degrees of certainty, to be related to a single historical person, namely Flavius Mauricius, a high military official of Late Antique Egypt. A likely connection between five of these pieces of evidence was previously suggested by Gascou (1998); linking fewer of them was proposed among others also by the authors of the PLRE I (s. v. Mauricius 1), Hagedorn (1979), Baldwin (1982: pp. 104-105), Kaster (1988: p. 265), Carrié (2005: p. 17) and Miguélez Cavero (2008: pp. 82-83). The contemporary texts to be discussed comprise two papyri (1-2) and three inscriptions (3-5), the former containing a judicial proceedings record, the latter being a building inscription, visitor's graffito, and a funerary inscription. The last of these texts (5) is the only one not recovered from Egypt but from the Balkans. All the inscriptions were written in Latin, while the papyrus is bilingual, combining Latin and Greek. The preserved contemporary evidence is further complemented by literary testimonies preserved in the Res Gestae of Ammianus Marcellinus (6), the Historia Nea of Zosimus (7), and Bibliotheke of Photius (8). Every piece of evidence is reviewed individually, followed by the evaluation of their varying likelihood to be in fact mentioning the same Flavius Mauricius, a tentative attempt at reconstruction of the probable course of his career and other hints about his life, and finally tackling the apparent prevalence of Latin in the discussed pieces of contemporary evidence. 


\section{The evidence}

\section{ChLA XLVII: $1431=$ POxy. LXIII: $4381(\text { TM 22144 })^{1}$}

recto:

Post çons(ulatum) d(omini) n(ostri) Gratiani per(petui) Aug(usti) III et Equitio v(iri) c(larissimi) com(itis) die III non(as) Aug(ustas) Alex(andreae) in secretario. [...]

Ex offic(io) d(ictum) est, 'cuiusmodi libellum Pelion duc(enarius) publice magnitudine tuae obtulerit prae manibus habentes [reci]tamus, si praecipis.'

Fl(avius) Mauricius, v(ir) c(larissimus), com(es) ord(inis) prim(i) et dux, d(ixit), 'legatur et

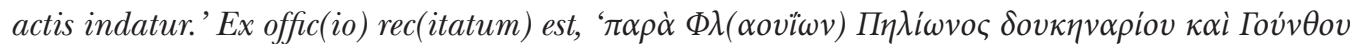
$\kappa[\iota \rho \kappa i \tau \omega \rho / \varepsilon v \tau \eta v \dot{\alpha} \rho\llcorner o \sigma \alpha \dot{\alpha} \rho] \theta \mu o \tilde{v}$

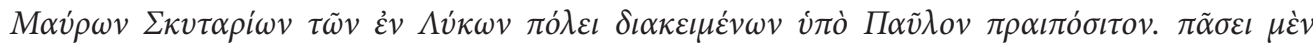

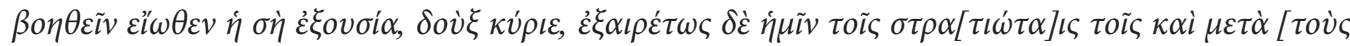

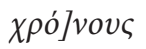

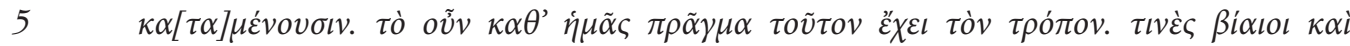

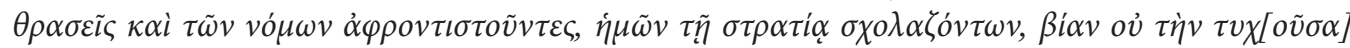
$v \pi \varepsilon \pi \circ \iota \dot{\eta} \kappa \alpha \sigma l v \tau[o \tilde{\iota} \varsigma \dot{\eta} \mu] \varepsilon \tau \dot{\varepsilon} \rho o \iota \varsigma$

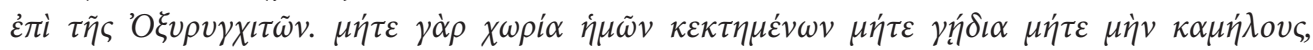

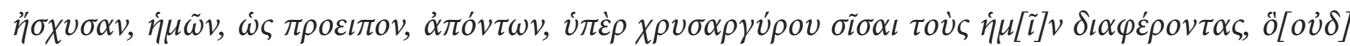
$\varepsilon[\pi] \dot{\omega} \pi \sigma \tau \varepsilon$

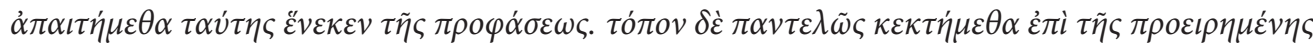

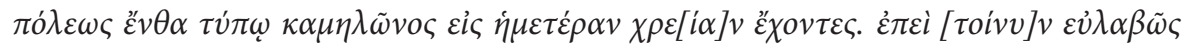

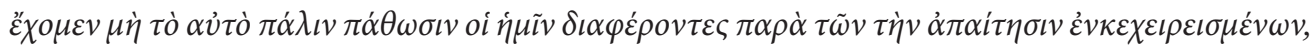

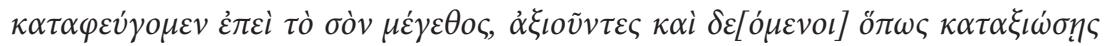

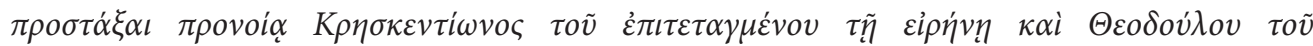

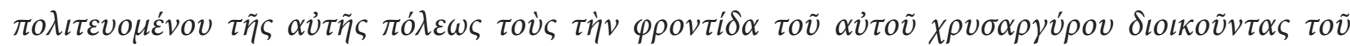

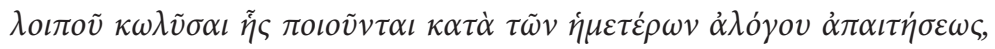

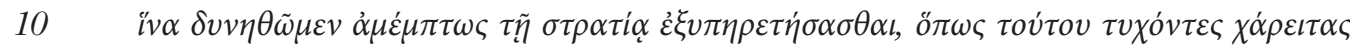

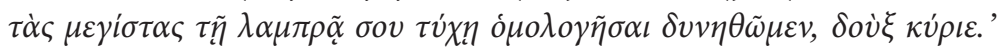

Fl(avius) Mauricius, v(ir) c(larissimus) com(es) ord(inis) prim(i) et dux, d(ixit), 'si nul![...]as exer[... pos]sessiones [...]ene $[. .] q u.[\ldots]$ argent $[\ldots]$ '

$[\ldots]$

verso:

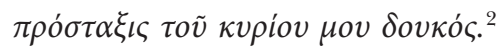

1 Modified according to Palme (2014).

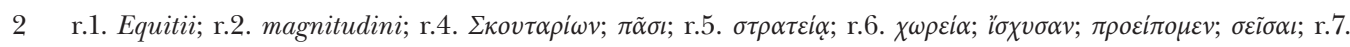

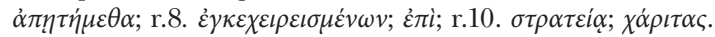

Translation (r.1-3): After the consulate of our lord Gratian, perpetual Augustus, for the $3^{\text {rd }}$ time and of Equitius, vir clarissimus, comes, on the $3^{\text {rd }}$ day before the Nones of August at Alexandria, in the council chamber. It was said by the staff, 'Having on our hands a petition of the sort which Pelion, ducenarius, presented to Your Highness in public, we will recite it, if you give an order.' Flavius Mauricius, vir clarissimus, comes ordinis primi, and dux, said, 'Let it be read and put in the records' It was recited by the staff, 'From Flavius Pelion, ducenarius, and Gounthus, circitor (or centenarius ?), of the numerus... 
The papyrus was recovered in Oxyrhynchus. It contains a bilingual judicial proceedings (inter alia Coles 1966; Palme 2014: pp. 482-486; Haensch 2016) which was dated by a consular date to August 3, 375 CE. The document and its implications for the study of the practice of law in Roman Egypt were recently examined in detail by Palme (2014: pp. 499-502; 2016: pp. 465-466; see also Adams 2003: pp. 557-558). The proceedings record a session of the military court which took place in the capital of Alexandria. The court was presided over by Flavius Mauricius who was identified by the titles of vir clarissimus, comes ordinis primi, and dux.

The matter of the lawsuit was a civil action taken by two Middle Egyptian military officers of the Cuneus Equitum Maurorum Scutariorum stationed in the city of Lycopolis (see also Not. Dig. Or. XXXI), at the time belonging to the province of Thebaid (see e.g. Palme 2007). The plaintiffs demand a ruling against an unlawful collection of taxes exacted from a camel stable, which they owned jointly in the city of Oxyrhynchus in the province of Augustamnica (see e.g. Palme 2007). Only the beginning of the judge's response is extant, and it is uncertain, whether the case was resolved immediately, or whether Mauricius demanded summoning of the defendants or other evidence. However, as noted by Palme (2014: pp. 500-501, see also pp. 498-499; Palme 2016: pp. 465-466), the lawsuit as such was in fact conducted in transgression of the law, as it was prohibited for civil actions, including filings of military plaintiffs against civil defendants, to be tried by military courts.

\section{2. $C E L$ I: $230=C h L A$ XII: 523 Ro $=$ PLips. 270 Ro (TM 69994)}

recto, 1 :

$[\ldots]$

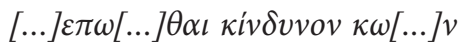

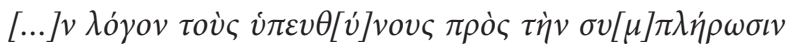

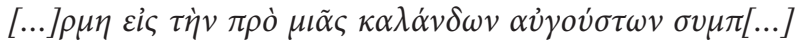

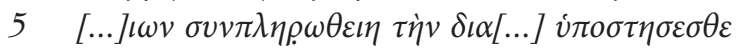

$[\ldots \dot{\varepsilon} \rho \rho \tilde{\omega} \sigma \theta] \alpha \iota \dot{\varepsilon} \rho \rho \tilde{\omega} \sigma \theta \alpha \iota \dot{\varepsilon} \rho \rho \tilde{\omega} \sigma \theta[\alpha] \iota$

recto, 2:

[...]

$[\ldots] \sin [\ldots]$

$[\ldots]$ de[...]etutus int $[. .$.$] em [...]$

$m[\ldots]$ universa redditi[bu]s atque [...] litteris [...]

5 c[l]arissim[i] Mauricii qui te nunc caruit prae ce[teris] nostris [...]

fecisse monstraveris [...] officium sed in a[...]as[...]

dispentio familiaris rẹi [s]uae sit seduli[ta]s [...]ti[...]

inpertienda cor noscas interea ne ad invidia[m hanc r]em $d[. .$.

ri[...]lus videatur e[...]ectus inducere $[\ldots]$ um [...]

$10[\ldots]$ conlata sati[s d]eposuit [...]em emitur pe[...]e[...]e[...]

$\sigma \dot{v} \mu \varepsilon, \delta \varepsilon \dot{\varepsilon} \sigma \pi \tau \alpha, \varphi v \dot{\lambda} \alpha \xi o v$,

$\sigma \dot{\eta} \mu \varepsilon \rho o ́ v \mu \varepsilon \delta \iota \alpha ́ \alpha \omega \sigma o v$

[...]v 


$$
[\ldots] \theta \varepsilon[\ldots] v^{3}
$$

Both sides of the heavily damaged papyrus were used for the recording of various texts. Only the recto side is relevant for this study. The bilingual text was proposed to represent a piece of official correspondence from the fourth century CE (Hagedorn 1979: p. 101), however, its exact meaning remains obscure. The only person mentioned in the fragment is a certain Maurcius, referred to as [vir?] clarissimus (Hagedorn 1979: p. 101), who was neither the writer, nor the addressee of the letter. The Latin part of the text is followed by what seems to be a Christian prayer in Greek. The place of origin is stated to be unknown by Hagedorn (1979: p. 101), however, in BL (VIII: p. 84), it is established to be Thebais.

\section{Bernand 1990: pp. 180-181 = Année Épigr. 1909: 108 (TM 106177) \\ Salvis $d d d$ (=dominis) nnn(=nostris) \\ Valentiniano Valente et \\ Gratiano semper Augustos \\ Fl(avius) Mauricius v(ir) c(larissimus) com(es) et dux, \\ 5 renovari iussit hunc locum. Fl(avius) Traianus p(rae)p(ositus) \\ cum Theb(anis) mil(itibus) reparavit. ${ }^{4}$}

The building inscription found in Aswan was dated by the names of the ruling emperors, Valentinian I (364-375 CE), Valens (364-378 CE), and Gratian (367-383 CE). Together, they shared the power in the years $367-375$ CE, i.e. the period in which the inscription must have been made. The text informs about a renovation of an unspecified structure, which was done upon the order of Flavius Mauricius, described as vir clarissimus, comes, and dux. The works are stated to be carried out by 'Thebani milites' ${ }^{5}$ under the supervision of a military officer in the rank of praepositus.

The particular find spot from which the inscription was recovered was interpreted by its excavators as a temple site (anonymous 1908; see also Cagnat 1896; Zawadzki 1969). As hinted later, the place also may have been the site of, or be located nearby, the military camp of Aswan's Roman garrison of the principate (CIL III, Suppl. 2: 14147'; Maxfield 2000; Pfeiffer 2015: p. 238). This possibility is corroborated by several other Latin inscriptions found at the same site (Année Épigr. 1909: 107; CIL III, Suppl. 2: 14147"-4; Zawadzki 1969). All of these were, some evidently, some likely, also commissioned by

3 r.2.8. impertinenda.

Translation (r.2.5): ...of [vir?] clarissimus Mauricius who missed you more than the rest of ours...

4 3. Augustis.

Translation: In the time of our lords Valentinian, Valens, and Gratian, forever Augusti, Flavius Mauricius, vir clarissimus, comes, and $d u x$, ordered this place to be restored. Flavius Traianus, praepositus, repaired it with the Theban soldiers.

5 There seems to be no further evidence corroborating the existence of a particular unit of this name (see esp. Not. Dig.); it may refer rather to the soldiers of the region in general. 
the army. ${ }^{6}$ The Aswan inscription of Mauricius is to a certain degree comparable with building inscriptions from other parts of the Empire (CIL III, 1: 88; CIL VIII, 2: 10937; CIL XIII: 11538; Southern \& Dixon 1996: Fig. 6), ${ }^{7}$ which are connected with Valentinian's and Valens's restoration of the system of frontier fortifications (Southern \& Dixon 1996: pp. 40-45). Thus, it seems possible that the structure repaired by Mauricius may also have been a military installation and, considering its find spot, possibly even the old auxiliary camp used since the principate.

\section{Baillet 1926: 1408 = Année Épigr. 1998: 1470 (TM 96088) \\ Mauricius $v$ (ir) c(larissimus) dux \\ vidi et miratus sum. ${ }^{8}$}

The short inscription of Mauricius painted with a black ink on the wall of the entrance corridor of the tomb KV 9 is, apart from the language it uses, a typical example of visitor's graffiti ${ }^{9}$ found in the Valley of the Kings (Baillet 1926; see also Foertmeyer 1989: pp. 25-29; Coppens 2016). With the inscription, the author intended to leave a memory of his visit to the site. He introduced himself as vir clarissimus and dux and states that he saw and admired in awe the royal tombs. Based on the appearance of the script, Baillet (1926: p. 343) could date the inscription only broadly to the period of fourth to sixth centuries CE.

The statements of (visual) examination as well as amazement counted among the usual ones expressed by the visitors to the tombs at the Valley of the Kings. In the GrecoRoman period the royal tombs, called Syringes (e.g. Pausanias: Hellados Periegesis I, 42), became one of the most popular touristic sites in Egypt and kept attracting attention long into Late Antiquity and possibly after. The tombs gained their fame principally as a monument to the technical and artisan skills of their makers. Apart from that, they were seen as places of wisdom and knowledge. In the sixth century the Valley of the Kings was settled by a community of Christian monks. The construction of tomb KV 9, in which the graffito of Mauricius was found, was initiated by Rameses V (ca. 1160-1156 BCE) and was subsequently finished and used by Rameses VI (ca. 1156-1149 BCE; Dodson 2016: pp. 220-221). In the Greco-Roman period, it was, however, believed to be the tomb of Memnon, the Homeric king of the Aethiopians. Thanks to that, this particular tomb has received by far most of the touristic attention. It is likely that it was perceived as such also by Mauricius. Notably, right next to Mauricius's inscription, there is another one (Baillet 1926: 1409) written in a very similar manner and also in Latin belonging to another

6 For the Roman military presence in Aswan see inter alia Speidel (1988); Eide et al. (1998: passim); Maxfield (2000: pp. 410-414).

7 Three of them (CIL III, 1. 88; CIL XIII: 11538; Southern \& Dixon 1996: Fig. 6) are dated to 371 CE. It may be possible that the reconstruction at Aswan took place in or close to $371 \mathrm{CE}$ as well.

8 Translation: I, Mauricius, vir clarissimus, dux, saw and admired (this place).

9 Inscriptions recording one's presence at a certain memorable site, often having religious subtext; for more on the genre in general see Foertmeyer (1989); Rutherford (2012). 
man with the title of comes whose name is too fragmentary to be reconstructed. Thus, it is likely that Mauricius was accompanied during his visit by another important official.

\section{Pilhofer 2009: 111/L554 = Année Épigr. 1983: 890 = Feissel 1983: 251 \\ Hic in pace requies \\ c[i]t in nomine \\ [Ch]risti Maurici \\ [us] vir clarissi \\ 5 [mus] ex comite. ${ }^{10}$}

A marble slab bearing the Latin epitaph was found covering a tomb at Philippi in ancient Macedonia. The tombstone belonged to Mauricius, named together with his titles of vir clarissimus and ex comite, i.e. former comes (inter alia RE: s. v. Comites).

Mauricius was buried in one of the oldest churches at Philippi, the so-called Basilica

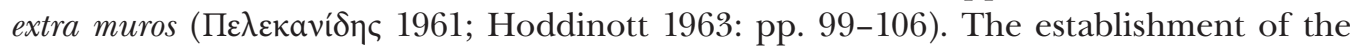
church was at first estimated by the excavator to have taken place in the beginning of

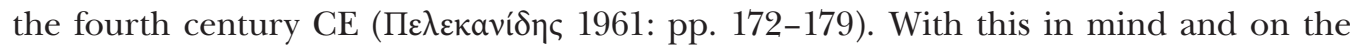
grounds of the language used along with the appearance of the script (see Pilhofer 2009:

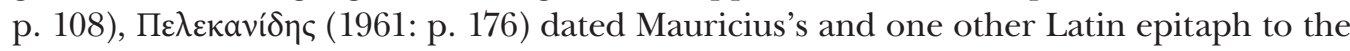
first decades of the fourth century CE. However, reconsidering the evidence, and especially the find of coins of Constantius II (337-361 CE) under the floor of the basilica, he himself later pushed the date of the establishment of the basilica to the middle of the

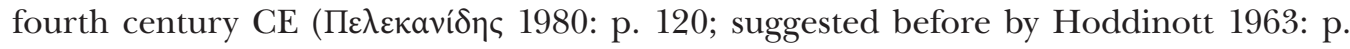
104). Thus, ${ }^{11}$ also his dating of Mauricius's epitaph is to be necessarily pushed at least to the same time and there seems to be no reason against presuming that it could be even later.

\section{Ammianus Marcellinus: Res Gestae XXV, 8, 7:}

Et via sex dierum emensa, cum ne gramina quidem invenirentur, solacia necessitatis extremae, dux Mesopotamiae Cassianus et tribunus Mauricius pridem ob hoc missus ad Ur nomine Persicum venere castellum, cibos ferentes ex his quos relictus cum Procopio et Sebastiano exercitus parcius victitans conservarat. ${ }^{12}$

\section{Zosimus: Historia Nea III, 33, 1:}

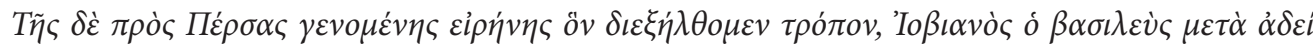

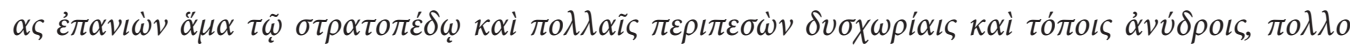

10 Translation: Here rests in peace, in the name of the Christ, Mauricius, vir clarissimus, a former comes.

11 Certain reservation to the originally proposed dating is apparent in both later editions of the inscription (Feissel 1983; Pilhofer 2009) and was explicitly expressed by the editor of Année Épigr. (1983: p. 252).

12 Translation: And after completing a six days' journey, during which not even grass has been found as a relief for the utmost need, Cassianus, dux of Mesopotamia, and tribune Mauricius, sent long before for that purpose, arrived at a Persian fortress called Ur, bringing the provisions from those which were saved by the army left with Procopius and Sebastianus by their frugal way living. 


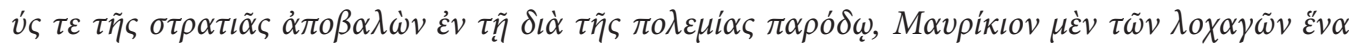

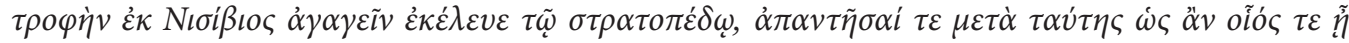
$\pi \circ \rho \rho \omega \tau \dot{\alpha} \tau \omega .^{13}$

According to both Ammianus Marcellinus and Zosimus, an officer Mauricius in the rank of a military tribune ${ }^{14}$ was sent in $363 \mathrm{CE}$ to acquire provisions for the Roman army retreating from Mesopotamia after the defeat by the Persians, the death of emperor Julian (360-363 CE), and the proclamation of Jovian (363-364 CE). However, the authors disagree on Mauricius's destination with it being either Ur or Nisibis. The testimony of Ammianus Marcellinus is to be favoured, as he participated personally on Julian's Persian campaign and its retreat led by Jovian (PLRE I, s. v. Ammianus Marcellinus 15). Zosimus was not a contemporary to these events; however, for his description of the period in question, he relied heavily on Eunapius (e.g. Goffart 1971: esp. p. 419), who lived concurrently, but did not participate in the affairs he described in person.

\section{Photius, Bibliotheke, Cod. 279, 536 a:}

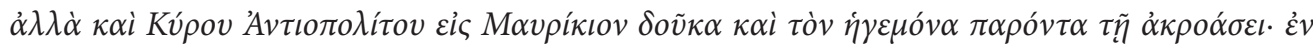

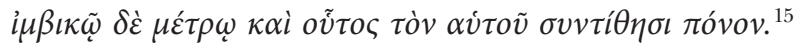

In his Bibliotheke, towards the end of the entry dedicated to the Chresomatheiai of Helladius of Antinoopolis, Photius names several other Iambic poets from Egypt, all likely composing during the second half of the fourth century CE (Miguélez Cavero 2008: pp. 79-80). One of them was Cyrus of Antaeopolis, who was mentioned to have composed an iambic encomion to Mauricius, followed by the Greek tiles of ' $\delta o v$ ' ' and ' $\eta \gamma \varepsilon \mu \omega v^{\prime}$ '. The first one is the Greek equivalent of $d u x$, the second one most likely refers to the governorly rank of praeses (see Mason 1974: pp. 148-149). Depending on the reading of the passage, either both titles should belong to Mauricius, or the second one is denoting yet another person, as it was proposed more recently by Hammerstaedt (1997: pp. 114-116) and Gascou (1998: p. 61; see also Miguélez Cavero 2008: p. 82).

13 Translation: When the peace was made with the Persians, manner of which I described in detail, the emperor Jovian was securely returning with his army, but he was encountering many difficulties of the terrain and places without water and he was losing many men of the army passing through the country of the enemy. Thus, he sent Mauricius, one of the tribunes, to bring provisions for the army from Nisibis and to come back as far as possible with it to meet him.

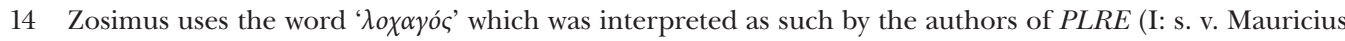
1). Such interpretation is supported by Mason (1974: p. 164).

15 Translation (following the interpretation after Hammerstaedt 1997 and Gascou 1998): And there is (a writing) of Cyrus of Antaeopolis on Mauricius, $d u x$, and a praeses, who were present at the hearing; he composed his work in a iambic metre. 
Tab. 1. Overview of the evidence.

\begin{tabular}{|c|c|c|c|c|c|}
\hline \multirow[t]{2}{*}{ No. } & \multirow{2}{*}{$\begin{array}{l}\text { Principal } \\
\text { Editions/ } \\
\text { Reference }\end{array}$} & \multirow{2}{*}{$\begin{array}{l}\text { Type of the } \\
\text { Text/ Medium }\end{array}$} & \multirow{2}{*}{$\begin{array}{l}\text { Date (of the } \\
\text { Evidence) }\end{array}$} & \multicolumn{2}{|c|}{$\begin{array}{l}\text { Evidence for Flavius } \\
\text { Mauricius }\end{array}$} \\
\hline & & & & Name & Titles \\
\hline 1 & $\begin{array}{l}\text { ChLA XLVII: } \\
1431 \text {; } \\
\text { POxy. LXIII: } \\
4381\end{array}$ & $\begin{array}{l}\text { judicial } \\
\text { proceedings/ } \\
\text { papyrus }\end{array}$ & $\begin{array}{l}\text { August 3, } 375 \\
\mathrm{CE}\end{array}$ & $\begin{array}{l}\text { Flavius } \\
\text { Mauricius }\end{array}$ & $\begin{array}{l}\text { vir clarissimus; } \\
\text { comes ordinis } \\
\text { primi; } \\
\text { dux }\end{array}$ \\
\hline 2 & $\begin{array}{l}\text { CEL I: 230; } \\
\text { ChLA XII: } 523 \\
\text { Ro; } \\
\text { PLips. } 270 \text { Ro }\end{array}$ & $\begin{array}{l}\text { official } \\
\text { correspondence } \\
\text { (?)/ papyrus }\end{array}$ & - & Mauricius & $\begin{array}{l}\text { [vir?] } \\
\text { clarissimus }\end{array}$ \\
\hline 3 & $\begin{array}{l}\text { Bernand 1990: } \\
\text { pp. 180-181; } \\
\text { Année Épigr. } \\
\text { 1909: } 108\end{array}$ & $\begin{array}{l}\text { building } \\
\text { inscription/ } \\
\text { stone }\end{array}$ & 367-375 CE & $\begin{array}{l}\text { Flavius } \\
\text { Mauricius }\end{array}$ & $\begin{array}{l}\text { vir clarissimus, } \\
\text { comes, } \\
d u x\end{array}$ \\
\hline 4 & $\begin{array}{l}\text { Baillet 1926: } \\
\text { 1408; } \\
\text { Année Épigr. } \\
\text { 1998: } 1470\end{array}$ & $\begin{array}{l}\text { Visitor's } \\
\text { graffito/ wall }\end{array}$ & $\begin{array}{l}\text { 4th-6th } \\
\text { century CE }\end{array}$ & Mauricius & $\begin{array}{l}\text { vir clarissimus, } \\
d u x\end{array}$ \\
\hline 5 & $\begin{array}{l}\text { Pilhofer 2009: } \\
\text { 111/L554; } \\
\text { Année Épigr. } \\
\text { 1983: 890; } \\
\text { Feissel 1983: } 251\end{array}$ & $\begin{array}{l}\text { funerary } \\
\text { inscription/ } \\
\text { stone }\end{array}$ & $\begin{array}{l}\text { after mid-4th } \\
\text { century CE }\end{array}$ & Mauricius & $\begin{array}{l}\text { vir clarissimus, } \\
\text { ex comite }\end{array}$ \\
\hline 6 & $\begin{array}{l}\text { Ammianus } \\
\text { Marcellinus: Res } \\
\text { Gestae XXV, 8, } 7\end{array}$ & $\begin{array}{l}\text { literary } \\
\text { testimony }\end{array}$ & $363 \mathrm{CE}$ & Mauricius & tribunus \\
\hline 7 & $\begin{array}{l}\text { Zosimus: } \\
\text { Historia Nea III, } \\
33,1\end{array}$ & $\begin{array}{l}\text { literary } \\
\text { testimony }\end{array}$ & $363 \mathrm{CE}$ & Mavpíkıৎ & $\lambda o \chi \alpha \gamma o ́ \varsigma$ \\
\hline 8 & $\begin{array}{l}\text { Photius, } \\
\text { Bibliotheke, Cod. } \\
279,536 \text { a }\end{array}$ & $\begin{array}{l}\text { literary } \\
\text { testimony }\end{array}$ & - & Mavpikıs & 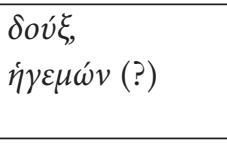 \\
\hline
\end{tabular}

\section{Evaluation of the evidence}

The presented set of evidence is very heterogeneous, comprising texts on various media, of various genres, and coming from various places and periods. While this is certainly opportune, however, it is also demanding in terms of evaluating both the individual pieces of evidence as well as the set as a whole. Thus, it is desirable, before proceeding with their synthesis, to examine closely the rate of certainty/uncertainty with which 
the pieces should be attributed to the same person, the $d u x$ Flavius Mauricius. Through such evaluation, it is possible to establish a tentative hierarchy of the individual pieces of evidence and, partly in subsequence, to single out some of them as a 'core' and the rest as 'peripheral' for the following constructions.

Overall, four of the contemporary sources (1-4) came from Egypt and one of the literary testimonies $(\mathbf{8})$ pertains to the same region as well. The rest comes from/deals with other regions of the eastern part of the Empire. Thus, their connection to the rest should be viewed with more caution. The dates and date-ranges attained individually for all of the pieces of evidence are compatible with one another. The name 'Mauricius' seems to be quite rare, both during the principate as well as during the dominate, at least in the rest of the third and in the fourth century CE (see inter alia Schulze 1933; PLRE I; Solin \& Salomies 1994: s. v. Mauricius; EDCS $).{ }^{16}$ Under such circumstances, it seems less likely that the otherwise coherent evidence would be produced in connection to more individuals with the same name, which, however, cannot be ruled out entirely.

Focusing on the various pieces of evidence individually, it is possible to divide them in the following manner. The core body of information about the dux Mauricius would consist of texts identifying him as the commander of the Roman army in Egypt, namely the judicial proceedings (1), building inscription (3), visitor's graffito (4), and the testimony of Photius (8). There may be only little doubt that all of them are pertaining to one and the same person. The Oxyrhynchus papyrus (1) identifies Mauricius by the fullest set of titles preserved. Moreover, it possesses an exact date. As such it must serve as a cornerstone for all following considerations, one against which all the other pieces of evidence are to be compared. Nearly the same set of titles is mentioned by the building inscription from Aswan (3), while its date range overlaps with the date of the judicial papyrus (1). The graffito from the Valley of the kings (4) also matches the other evidence well. In the case of this inscription, the omission of the title of comes may be problematic, which is further dealt with below. The identification of the addressee of the encomion mentioned by Photius (8) became essential for the debate about the date of the composition. As summarised by Miguélez Cavero (2008: p. 82), his identification with Mauricius of the other abovementioned texts has lately become the most plausible option.

The evidence linked with the previous texts only tentatively, and thus 'peripheral' for the following reconstruction, includes such pieces that do not mention Mauricius as the commander of the Egyptian military and/or come from/are pertaining to other regions of the Roman Empire than Egypt. These are the testimonies of Ammianus Marcellinus (6) and Zosimus (7), the uncertain papyrus fragment (2), and the epitaph from Philippi (5). The two historians (6-7) could be capturing Mauricius in the earlier stage of his career, which is an option suggested by the authors of PLRE (I: s. v. Mau-

16 Cf. also EDCS: the search query for 'maurici' returns 85 hits, out of which 6 are dated to the period before 400 CE [accessed September 23, 2020]. There were two well-known holders of the name in antiquity. St. Maurice is supposed to have been a soldier living in the third century CE, however, the first preserved mention of the saint comes only from the fifth century CE (Carrié 2005: p. 9; for St. Maurice in general see also other papers in Wermelinger et al. 2005). The other one is the emperor Maurice (582-602 CE). 
ricius 1). Such career progress was indeed possible (see e.g. Jones 1964: passim, esp. pp. 382, 383, 641, 643; Bodnaruk 2019: p. 313) and is discussed in detail below. The time gap between the dates of the Persian campaign (6-7) and the judicial papyrus (1) is twelve years which should also not be too much for it to be possible to happen. The likely link between the fragmentary papyrus (2) and the Egyptian commander was suggested by Hagedorn (1979: p. 101). However, both the date and the means of identification of the person mentioned are too unspecific to be sure at any rate. Too undefined as well is the information contained in the Macedonian funerary inscription (5). The titles mentioned on the tombstone could fit Mauricius's previous career but both were quite widespread and could be at the same time held by numerous individuals (see RE: s. v. Comites, F; Jones 1964: pp. 104-105, 526). Considering the physical appearance of the tombstone, there would be enough space to mention also other functions and honours, in case this would be desired. On the other hand, the occurrence of the titles mentioned was very rare at the city of Philippi, as was the use of Latin by Christian inscriptions (Ogereau 2018: pp. 100-101). This could both serve as supporting evidence for the possibility of the buried person being either of non-local origin or at least having an extraordinary reach to the high echelons of the government. As argued above, the dating of the inscription to the second half of the fourth century or later, could fit the period of Mauricius's lifetime. However, the physical distance of the Philippi inscription (5) from Egypt as well as the absence of any other titles in it remain the main caveat to be observed in its respect.

\section{Analysis of the evidence and discussion}

The name and titles of dux Mauricius were recorded in the most comprehensive way by the Oxyrhynchus judicial proceedings (1). He was twice referred to as 'Flavius Mauricius, vir clarissimus, comes ordinis primi et dux'. There are no more names or titles to be added from other sources. The military tribune recorded by Ammianus Marcellinus (6) and Zosimus (7) would not be held simultaneously with the provincial command.

The name 'Flavius' $(\mathbf{1}, \mathbf{3})$, was originally one of the more common nomina gentilia, especially as it was the family name of the Flavian and Constantinian imperial dynasties. During the dominate, together with other imperial nomina gentilia, namely 'Valerius' and 'Aurelius', it started to signify social rank rather than familial relation (Salway 1994: pp. 137-141). The name 'Flavius' would most probably be added to one's name on a certain appointment demonstrating his status as closely related to the imperial family (Salway 1994: p. 138). Thus, it seems probable that Mauricius did not hold the name at birth but started to use it only after some point in his career. It is the cognomen 'Mauricius', his personal name, that may shed some light on his family's origin. As noted above, the name was quite rare. It was derived from the ethnonym as well as cognomen 'Mauricus' (see $O L D$, s. v. Mauricus), relating to the native inhabitants of the former kingdom of Mauretania; the particular form 'Mauricius' is in accord with the development observed in Roman onomastic of the third and fourth centuries CE (Salway 1994: pp. 136-137). 
The name may point to the origin of dux Mauricius in the western part of the Roman Empire and in the westernmost part of the Roman Africa in particular.

At the height of his career, as far as it is attested, Flavius Mauricius held simultaneously three distinct titles, namely vir clarissimus $(\mathbf{1}-\mathbf{5})$, comes $(\mathbf{3}, \mathbf{5})$ ordinis primi $(\mathbf{1})$, and $d u x(1,3-4,8)$. The first two designated him as a member of two distinct orders of nobility, the third one described his position in the military hierarchy.

The old honorific title vir clarissimus (Jones 1964: passim, esp. pp. 527-545; Heather 2008; Skinner 2008) belonged to the members of the senate long before the dominate. Apart from being hereditary in the traditional senatorial families (Jones 1964: p. 528), by the fourth century CE it was commonly awarded to various officers upon reaching certain grades of the administrative or military hierarchies (Jones 1964: passim; Heather 2008: p. 190). It seems that it could have been conferred also in connection with the comitiva ordinis primi (Mitthof 1995: p. 115; Bodnaruk 2019: pp. 122-123, see also pp. 69-72). In $372 \mathrm{CE}$, and thus likely already during Mauricius's Egyptian tenure, a further grading of the senatorial order was codified with the viri clarissimi remaining members of the lowermost of the three tiers (Jones 1964: p. 143; Heather 2008: p. 190; Bodnaruk 2019: pp. 122-123). The duces originally belonged among the equites, and only by the rule of Valentinian I (364-375 CE) and Valens (364-378 CE) they started regularly to become viri clarissimi, and around $400 \mathrm{CE}$ they started to appear as members of the intermediate senatorial rank of viri spectabiles (Jones 1964: pp. 48, 135, 142-143, 527; Southern \& Dixon 1996: p. 60; Bodnaruk 2019: pp. 71-72, 314; cf. Jones 1964: pp. 143, 528-529; Heather 2008: p. 190; see also PLRE I: esp. pp. 1118-1121; Mitthof 1995: pp. 115-116). Mauricius was likely not of senatorial descent and he was likely elevated to this rank of nobility on his appointment to the high military command.

The codification of the order of imperial companions, the comites, represented an innovation to the imperial hierarchy introduced in the fourth century CE. During the century, comitiva had undergone a complex development including grading, diversification, and gradual change of significance of the order, all of which is still not fully understood (Jones 1964: passim, esp. p. 526; Scharf 1994; Marcone 2008: p. 353; Bodnaruk 2019: pp. 62-75). The graded comitiva included three tiers of which the comitiva ordinis primi was the highest one (Jones 1964: passim; Scharf 1994; Mitthof 1995; Bodnaruk 2019: p. 62). In the third quarter of the fourth century the comitiva ordinis primi began to be awarded on a regular basis, however, most likely not automatically, to active holders of certain offices, including duces (Scharf 1994; Bodnaruk 2019: pp. 63, 69; see also PLRE I: esp. pp. 1118-1121; Mitthof 1995). It is probable that the exact designation of the honour was regularly abbreviated and many holders of the corresponding offices of this time identified only as comites were in fact comites ordinis primi (Bodnaruk 2019: p. 63). This is suggested also by comparison of the Oxyrhnychus proceedings (1) and the Aswan building inscription (3). The rank of comes was conspicuously omitted from one of the texts, namely the visitor's graffito from the Valley of the Kings (4). Considering the appearance and physical context of the inscription, it seems that this was not an omission out of necessity. Thus, it is possible that Mauricius was admitted to the comitiva only sometime after his appointment to the Egyptian command and this would place the visitor's graffito earlier than the two pieces 
mentioning the title of comes $(\mathbf{1}, \mathbf{3})$. It is hard to interpret with certainty the title of $e x$ comite, i.e. former comes, mentioned by the epitaph from Philippi (5). It could designate a former active holder of comitiva (ordinis primi or any other). It could, however, be also granted as a mere formal honour without the necessity of actual previous service (inter alia RE: s. v. Comites; Jones 1964: pp. 104-105, 530). Only in the former case could the tombstone belong to Flavius Mauricius, the dux of Egypt.

The principal title, military rank, and the actual office held by Flavius Mauricius during his service in Egypt was that of dux. Duces were the lowermost members of the high command of the imperial military. From the time of the tetrarchy they were given the military authorities formerly held by the provincial governors and were tasked with the command and administration of the borderland forces (inter alia Jones 1964: passim, esp. pp. 608-610; Southern \& Dixon 1996: pp. 59-60; Bodnaruk 2019: pp. 313-331). The earliest attested military commanders of Egypt with this rank were designated as $d u x A e-$ gypti et Thebaidos utrarumque Libyarum (PLRE I: s. v. Aur. Maximinus 10, Val. Rometalca). Later, the exact geographical specification often ceased to be stated in full or entirely, as it was likely considered obvious what the extent of the authority of the Egyptian $d u x$ was. However, it seems almost certain that its extent did not change until the last quarter of the fourth century in which the organisational structure of Egyptian military was reformed. A new post of comes (rei militaris) limitis Aegypti has essentially inherited the authority of the former $d u x$ and two new duces were created to command, as his subordinates, the Thebais and the Libyan provinces (inter alia Not. Dig. Or. I, XXVIII; Southern \& Dixon 1996: p. 60; Palme 2007: p. 247).

As no source states the territory for which Flavius Mauricius was responsible, in the past, there has been some confusion of what it was. The authors of the PLRE I (s. v. Fl. Mauricius 2) have assumed that he was dux Thebaidos, likely due to the fact that they did not have at hand the Oxyrhynchus papyrus (1) published only in 1996 (POxy. LXIII: 4381). After its publication, the need to revise this interpretation has been noted (e.g. Carrié 2005: p. 17; Bodnaruk 2019: pp. 69, 326; see also Gascou 1998: p. 63). As it is clearly demonstrated by the various pieces of evidence, especially the Oxyrhynchus papyrus (1) and the building inscription at Aswan (3), the authority of Flavius Mauricius must have encompassed the whole of Egypt with all its provinces. Moreover, this assumption, as opposed to the former one, is well in accordance with the current understanding of the development of the military administration of Egypt in the Late Antiquity.

Considering this fact as well as other evidence, it is possible at least generally to date Mauricius's Egyptian tenure. He must have held the office of $d u x$ in August of $375 \mathrm{CE}$ (1). His last known predecessor as $d u x$ Aegypti was a certain Traianus (PLRE I: s. v. Traianus 2). Traianus held this office with certainty still in May of $368 \mathrm{CE}$, giving the terminus post quem for Mauricius's appointment. If Mauricius was indeed his direct successor, he would have entered the office before/in $371 \mathrm{CE}$, in which year Traianus had already served as comes rei militaris on the eastern border. ${ }^{17}$ There is no evidence for Mauricius staying in the office of $d u x$ after $375 \mathrm{CE}$.

17 Note also the possible dating of the Aswan building inscription (3) (see note no. 7 above). 
As noted for example by Palme (2007: p. 247), in Egypt of the fourth century CE, the authority of its military commander apparently surpassed that of the provincial governors as well as any other regular officeholders in the land. In the case of Flavius Mauricius, this is very clear. As referred to by patriarch Photius (8), it was deemed appropriate for him to be honoured by a poetic composition. On the one hand he was apparently lauded together with the provincial governor, but, as Mauricius is mentioned as first and by name as opposed to his civil counterpart, he could have been given precedence. Another evidence of his authority is given by the Oxyrhynchus judicial proceedings (1). It shows not only that he was likely the preferred, or the only effective, instance for the plaintiffs to seek justice from, but especially that he was likely able to carry through his actions as a judge even though they apparently transgressed the law to the prejudice of the civil administration of the province.

Beyond Egypt, any assumptions about Mauricius's career and life must remain tentative. Before becoming the $d u x$, he was possibly a military tribune in the field army of Julian in $363 \mathrm{CE}$ (6-7). It is possible that he distinguished himself through his service during the campaign which may have contributed to his further career advancement. As hinted above, the rank of the military tribune was in the military hierarchy just below that of $d u x$ and recruitment of duces from tribunes was not unusual (see e.g. Jones 1964: passim, esp. pp. 382, 383, 641, 643; Bodnaruk 2019: p. 313). As these two career steps would be separated by more or less a decade, this would be more than enough time to secure the promotion. There is no certainty to what happened with Flavius Mauricius after 375 CE. As elaborated above, there seems to be nothing that would disprove the possibility of Mauricius being buried at Philippi in Macedonia. On the other hand, there is no other evidence to support it or even to explain him getting there. However, in the context of the Roman Empire of the fourth century CE, this would seem not to be at all unlikely, for reasons such as consequent continuation of service at or closer to the imperial court or ownership of an estate at Philippi or nearby. Both these and any other possibilities would, however, be speculative at best.

Viewing the torso of the career of Flavius Mauricius in its plausible entirety, it seems that his Egyptian tenure represented its highlight or was just below the apex. If he had risen higher, the likelihood of having at least some evidence for it would seem to be quite high. If he in fact ended his rise as $d u x$ or shortly after, this could indicate that he started his career quite low in the military ranks. On the other hand, it was unusual for common soldiers to raise above the ranks of lower officers (Jones 1964: passim, esp. p. 550), but even such cases did appear (Jones 1964: pp. 550, 556, 618). It seems most likely that Mauricius did not start his career from the very bottom of the military (see Jones 1964: pp. 641-642).

If the tombstone from Philippi (5) really belongs to Flavius Mauricius, it could mean that at least by the end of his life, he was a Christian and this may be supported also by the uncertain papyrus fragment (2), where he was mentioned presumably in Christian context as well. On the other hand, the visitor's graffito (4) from the supposed tomb of the Homeric hero Memnon could point to his appreciation of the pagan cultural tradition as well, something which would not be extraordinary in this period. Such 
appreciation may also suggest that Mauricius underwent at least some kind of formal education.

\section{The use of Latin in connection with dux Mauricius ${ }^{18}$}

Another striking feature of the set of evidence likely and possibly concerning dux Flavius Mauricius is the language. All five texts contemporary to the life and career of the Egyptian commander were either fully or at least partly written in Latin. It is even more striking as the two epigraphic pieces of evidence, the building inscription from Aswan (3) and the visitor's graffito from the Valley of the Kings (4) are currently one of the latest precisely datable appearances of Latin in the public space in Egypt. Later by a decade is only one statue base from Alexandria (CIL III, Suppl. 1: 6587). The issue of language choice for abovementioned pieces of evidence is to be considered separately and altogether to reveal possible clues for the reasons behind the preference of the use of Latin by Mauricius and his vicinity. Generally, it should be viewed also in the context of the new emphasis put on the use of Latin on official occasions during the tetrarchy (inter alia Bagnall 1993; Feissel 2010; Rudolf Haensch: pers. comm.).

It is to be noted that the use of Latin in the judicial proceedings (1) was strictly reserved for the framing parts of the text and speeches of Flavius Mauricius, the judge. The rest of the document, i.e. the cited petition of the plaintiffs, is in Greek. This application of bilingualism was typical for this kind of judicial proceedings in the late antiquity (Palme 2014: pp. 496-498; Haensch 2016). Adams (2003: pp. 557-558) noted as unusual the use of Latin in the speeches of Mauricius and interpreted it in the frame of his consideration of Latin as the 'language of power' (Adams 2003: passim, esp. pp. 545-576). Mauricius was by far not the only judge using Latin in recorded court speeches (e.g. ChLA IV: 254; ChLA XLI: 1204; ChLA XLII: 1226). Palme has pointed out that this feature was especially typical for the proceedings of the fourth century CE (Palme 2014: pp. 557-558). Thus, the use of Latin in the document depended, rather than on personal preference of Mauricius, on the contemporary custom and demonstration of him representing the imperial authority. Nonetheless, it is to be stressed again that the application of the above mentioned ideal 'rules' of bilingualism in judicial proceedings was strict and practically flawless in the case of the papyrus of Mauricius (1), while it is possible to find various irregularities favouring Greek elsewhere.

Given the uncertain contents of the other fragmentary papyrus (2), also the reasons for its partial use of Latin remain obscure. They were most likely connected to the apparent official nature of the correspondence (Hagedorn 1979: p. 101). It is to be noted that Mauricius was neither the sender nor addressee and, thus, the choice of language most likely did not concern his person in any way.

Mauricius's building inscription from Aswan (3) is the second latest of ca. two dozen Latin building and dedicatory inscriptions recovered from Egypt and datable from the

18 This section partly relies on the preliminary results of the author's ongoing dissertation project titled Latin in Egypt. As such it may undergo further refinement and reconsideration in the future. 
last decades of the third to the end the fourth century CE. ${ }^{19}$ In this time, these types of inscription seem to have been more common than before and together they comprised the clear majority among epigraphic attestations of Latin from Egypt. They were in most cases commissioned by men from the high echelons of the administration. With the exception of the inscription of Mauricius (3) and the Alexandrian statue base (CIL III, Suppl. 1: 6587), they all come from the time up to the rule of Constantine I (306-337 $\mathrm{CE})$. Some of them form groups related to three ambitious military building projects of the tetrarchy (see also Pollard 2013), namely the foundation of several auxiliary forts at various locations in Egypt in 288 CE (CIL III, 1: 22; CIL III. Suppl. 2: 13578; Année Épigr. 2013: 1736; see also Colin 2012), the establishment of the legionary fortress in Luxor (Lacau 1934: B-D, I-L, also dedications Lacau 1934: pp. 33-35, IV A-C; see also El-Saghir et al. 1986), and building activities at Abu Sha'ar on the coast of the Red Sea (Bagnall \& Sheridan 1994). If indeed, as argued above, Mauricius's repair project (3) did concern a military installation, likely in context of an empire-wide building programme, it could be readily compared to the building activities of the tetrarchy. The use of Latin likely seemed more than appropriate (see Adams 2003: passim, esp. pp. 545-576) in the context of projects of such magnitude sanctioned by no less than the imperial authority.

While in the Aswan inscription (3) and in the judicial papyrus (1) Mauricius appears in his official capacity, he is likely encountered acting as a private person during his visit to the Valley of the Kings (4). ${ }^{20}$ In the Late Antiquity, he was one of several men of a rank similar to his to visit the royal tombs (e.g. Baillet 1926: inter alia 482, 1282, 1311, 1379, $1409,1720,1827 b)$. In the context of the other inscriptions from the tombs, Latin was used by this category of visitors significantly. It seems that in some cases they may have decided to use it to underscore their status even in the case of a likely private occasion. However, other reasons for the language choice, e.g. preference of one's mother tongue or the official character of the visit, are not to be excluded entirely.

The use of Latin for an epitaph in the Macedonian city of Philippi (5) is remarkable (Ogereau 2018: pp. 100-101). It is certain that in this case Latin was not used for convenience. It had to be used on a special request of the person commissioning the tombstone. As in the previous case, the reasons for this choice remain uncertain, with self-presentation being probably the most likely one.

It is by no means possible to assert Flavius Mauricius as a native speaker of Latin or that he preferred to use it in his everyday conduct. Both options are, however, not to be excluded, also for the possibility of him being of western descent. Considering the evidence, a certain personal emphasis on the use of Latin seems clear, very likely beyond what would be caused only by factors external to Mauricius's own decision-making. This may have happened for various reasons, likely even in their coincidence. It is possible to see the language choices of Mauricius as a result of conservativism in the time in which

19 CIL III, 1: 17, 18, 19, 22; CIL III, Suppl. 1: 6584, 6633; CIL III, Suppl. 2: 12050, 12073, 13578, Lacau 1934: pp. 33-35, IV A-C, B-D, I-L; Bagnall \& Sheridan 1994: pp. 159-163; Année Épigr. (2013: 1736).

20 For visits with official subtext documented at the Colossi of Memnon see esp. Adams (2003: pp. 546-555), also Bernand \& Bernand (1960); Foertmeyer (1989: pp. 23-25); for a possible similar occurrence in the Valley of the Kings e.g. CIL III, 1: 67. 
the general emphasis on the use of Latin introduced during the tetrarchy has already been waning out. Alternatively, the preference of Latin could support his legitimization, as he was possibly a 'homo novus' in the top tier of the administration, or he just wished to underscore his closeness to the imperial authority. In any way, the language use of Mauricius represents a notable case of continuity perhaps not only with the changes from the beginning of the fourth century CE.

\section{Conclusions}

Dux Flavius Mauricius could have been of western or even western African descent. He probably did not come from the ranks of the Roman elite but, on the other hand, he possibly did not lack a formal education. Apparently, he began his military career during the rule of the Constantinian dynasty. It is not clear whether he began his advancement from the ranks, or whether he started his service directly as an officer. By $363 \mathrm{CE}$, he was likely a military tribune in the army of the emperor Julian and participated in his campaign to Persia. During Jovian's retreat, he would have been charged with the emergency procurement of provisions. He could have distinguished himself by this venture which may have boosted his career. Sometime between May of 368 and August of 375 $\mathrm{CE}$, and likely before or in 371 , he took over the command of the army in Egypt as $d u x$ and received, although maybe not immediately, other honorary titles as well. His authority reached across all of the Egyptian provinces and both Libyan ones as well. During his tenure he ordered an unspecified (likely military) installation to be rebuilt at Aswan. At some point in his office he visited western Thebes and the Valley of the Kings in particular. Possibly in course of the same voyage he was together with the praeses (of Thebaid?) honoured by Cyrus of Anteaeopolis through his encomion. In August of 375 CE, Flavius Mauricius was in Alexandria where he presided over a session of the military court, in which he tried a civil case against the unlawful extortion of taxes at the city of Oxyrhynchus. The acceptance of the legal action by his court was unlawful, but likely in accord with the common practice. Sometime after $375 \mathrm{CE}$, he either left the office or died in service. In the former case, for an unknown reason, he may have moved from Egypt. Under unknown circumstances, he may have been buried in the Basilica extra muros at Philippi. In such case, it would be confirmed that Mauricius was a Christian. Regardless, he likely found appreciation also for the pagan component of the Greco-Roman culture. For some reason, Mauricius apparently preferred to a certain degree to use Latin instead of Greek.

The collation, re-evaluation and synthesis of several pieces of diverse evidence has allowed to shed at least a dim light on various aspects of the life and career of Flavius Mauricius, the commander of the Roman military in Egypt. Not only Mauricius himself but also the individual pieces of evidence about him could be more firmly and accurately placed into their context. The new pieces of information may contribute to a better understanding of the political, social, and cultural developments in Egypt and the whole Roman Empire in the time in which they both went on many levels through 
a dynamic change. If the assumptions, among others of Mauricius's beliefs, education, and language preference, should prove right, he could, like many of his contemporaries, be embracing some of the ongoing changes, while in other cases clinging firmly to the established tradition.

\section{Abbreviations}

Année Épigr. = L'Année épigraphique.

$B L=$ Berichtigungsliste der griechischen Papyrusurkunden aus Ägypten .

$C E L=$ Corpus epistolarum latinarum papyris tabulis ostracis servatarum.

ChLA = Chartae Latinae Antiquiores.

$C I L=$ Corpus Inscriptionum Latinarum.

EDCS = Epigraphik-Datenbank Clauss / Slaby.

$O L D=$ Oxford Latin Dictionary.

PLips. = Griechische Urkunden der Papyrussammlung zu Leipzig.

PLRE I = The Prosopography of the Later Roman Empire, Vol. I.

POxy = The Oxyrhynchus Papyri.

$\mathrm{TM}=$ Trismegistos database.

\section{Bibliography}

Adams, J. N. (2003). Bilingualism and the Latin Language. Cambridge: Cambridge University Press. Anonymous. (1908). Recent Discoveries in Egypt. Proceedings of the Society of Biblical Archaeology, 30 (38 ${ }^{\text {th }}$ Session), 72-74.

Bagnall, R. S. (1993). Egypt in Late Antiquity. Princeton: Princeton University Press.

Bagnall, R. S., \& Sheridan, J. A. (1994). Greek and Latin Documents from 'Abu Sha'ar. The Bulletin of the American Society of Papyrologists, 31(3-4), 109-120.

Baillet, J. (1926). Inscriptions grecques et latines des tombeaux des rois ou syringes à Thèbes. Le Caire: Imprimerie de l'Institut français d'archéologie orientale.

Baldwin, B. (1982). Some Addenda to the Prosopography of the Later Roman Empire. Historia: Zeitschrift für Alte Geschichte, 31(1), 97-111.

Berichtigungsliste der griechischen Papyrusurkunden aus Ägypten. (1922-).

Bernand, A., \& Bernand, E. (1960). Les inscriptions grecques et latines du Colosse de Memnon. Paris: Institut Français d'Archéologie Orientale.

Bernand, E. (1990). A propos d'une inscription grecque d'Eléphantine. Zeitschrift für Papyrologie und Epigraphik, 82, 179-181.

Bodnaruk, M. (2019): Production of Distinction: the representation of Senatorial Elites in the Later Roman Empire, 306-395. Ph.D. Thesis. Budapest: Central European University.

Broux, Y. (2019). Life portraits: people of a multicultural generation. In K. Vandorpe (Ed.), A companion to Greco-Roman and late antique Egypt (pp. 395-404). Chichester: John Wiley \& Sons. 
Cagnat, R. (1896). Quatre inscriptions latines inédites d'Assouan. Comptes rendus de l'Académie des Inscriptions et Belles-Lettres, 40(1), 37-45.

Carrié, J.-M. (2005). Des Thébains en Occident? Histoire militaire et hagiographie. In O. Wermelinger, P. Bruggisser, B. Näf, \& J.-M. Roessli (Eds.), Mauritius und die Thebäische Legion: Akten des internationalen Kolloquiums: Freiburg, Saint-Maurice, Martigny, 17.-20. September 2003 (pp. 9-35). Fribourg: Academic Press Fribourg.

Chartae Latinae Antiquiores. (1954-).

Clauss, M., Kolb, A., Slaby, W. A., \& Woitas, B. (-2020). Epigraphik-Datenbank Clauss / Slaby [online available at: http://db.edcs.eu/epigr/epi.php?s_sprache=en; accessed 23.09.2020].

Coles, R. A. (1966). Reports of Proceedings in Papyri (Papyrologica Bruxellensia, 4). Bruxelles: Fondation Égyptologique Reine Élisabeth.

Colin, F. (2012). La Dédicace de Fondation Latine du Fort. In Idem (Ed.), Bahariya I: le fort romain de Qaret el-Toub I (pp. 103-117). Le Caire: Institut Français d'Archéologie Orientale.

Coppens, F. (2016). Chapter 31: Late Dynastic, Graeco-Roman and Christian Times; Post-New Kingdom Graffiti. In R. H. Wilkinson, \& K. R. Weeks (Eds.), The Oxford Handbook of the Valley of the Kings (pp. 469-480). Oxford: Oxford University Press.

Corpus Inscriptionum Latinarum. (1863-).

Cugusi, P. (1992-2002). Corpus epistolarum latinarum papyris tabulis ostracis servatarum (3 vols.). Florence: Gonnelli.

Depauw, M., Baetens, G., Broux, Y., Clarysse, W., Dogaer, N., Gheldof, T., Verreth, H. et al. (2011-2020). Trismegistos database [online available at: http://www.trismegistos.org; accessed 23.09.2020].

Dodson, A. (2016). Royal tombs of the twentieth dynasty. In H. Wilkinson, \& K. R. Weeks (Eds.), The Oxford Handbook of the Valley of the Kings (pp. 218-229). Oxford: Oxford University Press.

Eide, T., Hägg, T., Holton Pierce, R., \& Török, L. (Eds.). (1998). Fontes Historiae Nubiorum, III: From the First to the Sixth Century AD. Bergen: John Grieg AS.

El-Saghir, M., Golvin, J.-C., Reddé, M., Hegazy, S., \& Wagner, G. (1986). Le camp romain de Louqsor. Le Caire: Institut Français d'Archéologie Orientale.

Feissel, D. (1983). Recueil des inscriptions chrétiennes de Macédoine du III a au VI siècle (Suppléments au Bulletin de Correspondance Hellénique, 8). Athènes: École française d'Athènes.

Feissel, D. (2010). Documents, droit, diplomatique de l'Empire romain tardif. Paris: Association des amis du Centre d'histoire et civilisation de Byzance.

Foertmeyer, V. A. (1989). Tourism in Graeco-roman Egypt. Ph.D. Thesis. Princeton: Princeton University.

Gascou, J. (1998). Ducs, praesides, poètes et rhéteurs au Bas-Empire. Antiquité Tardive, 6, 61-64.

Goffart, W. (1971). Zosimus, The First Historian of Rome's Fall. The American Historical Review, $76(2), 412-441$.

Griechische Urkunden der Papyrussammlung zu Leipzig. (1906-).

Haensch, R. (2016). Die Protokolle der Statthaltergerichte der spätantiken Provinzen Ägyptens. In R. Haensch (Ed.), Recht haben und Recht bekommen im Imperium Romanum (The Journal of Juristic Papyrology, Suppl. XXIV; pp. 299-324). Warszawa: Faculty of Law and Administration of the University of Warsaw. 
Hagedorn, D. (1979). Zwei Neue Leipziger Papyri. Zeitschrift für Papyrologie und Epigraphik, 34, 101-107.

Hammerstaedt, J. (1997). Photius über einen verlorenen Codex mit Autoren des vierten Jahrhunderts n. Chr. aus Mittel- bzw. Oberägypten. Zeitschrift für Papyrologie und Epigraphik, 115, 105-116. Heather, P. (2008). Senators and Senates. In A. Cameron, \& P. Garnsey (Eds.), The Cambridge Ancient History, 13: The Late Empire, A.D. 337-425 (pp. 184-210). Cambridge: Cambridge University Press.

Hoddinott, R. F. (1963). Early Byzantine churches in Macedonia and southern Serbia. A Study of the Origins and the Initial Development of East Christian Art. London: Palgrave Macmillan.

Jones, A. H. M. (1964). The Later Roman Empire, 284-602. A Social, Economic and Administrative Survey (3 vols.). Norman: University of Oklahoma Press.

Jones, A. H. M., Martindale, J. R., \& Morris, J. (1971). The Prosopography of the Later Roman Empire (Vol. I). Cambridge: Cambridge University Press.

Kaster, R. A. (1988). Guardians of the Language: The Grammarian and Society in Late Antiquity. Berkeley - Los Angeles - London: University of California Press.

L’Année épigraphique. (1888-).

Lacau, P. (1934). Inscriptions latines du temple de Louxor. Annales du Service des Antiquités de l'Égypt, 34, 17-46.

Marcone, A. (2008). Late Roman Social Relations. In A. Cameron, \& P. Garnsey (Eds.), The Cambridge Ancient History, 13: The Late Empire, A.D. 337-425 (pp. 338-370). Cambridge: Cambridge University Press.

Mason, H. J. (1974). Greek Terms for Roman Institutions. A Lexicon and Analysis (American Studies in Papyrology, 13). Toronto: Hakkert.

Maxfield, V. A. (2000). The deployment of the Roman auxilia in Upper Egypt and the Eastern Desert during the principate. In E. Birley, G. Alföldy, B. Dobson, \& W. Eck (Eds.), Kaiser, Heer und Gesellschaft in der Römischen Kaiserzeit: Gedenkschrift für Eric Birley (pp. 407-444). Stuttgart: Franz Steiner Verlag.

Miguélez Cavero, L. (2008). Poems in Context: Greek Poetry in the Egyptian Thebaid 200-600 AD (Sozomena. Studies in the Recovery of Ancient Texts, 2). Berlin - New York: Walter de Gruyter.

Mitthof, F. (1995). Remigius comes primi ordinis et praefectus Augustalis. Zeitschrift für Papyrologie und Epigraphik, 109, 113-118.

Ogereau, J. M. (2018). The Social Constituency and Membership of the First Christian Groups at Philippi: A Literary and Epigraphic Survey. In J. R. Harrison, \& L. L. Welborn (Eds.), The First Urban Churches 4: Roman Philippi (pp. 79-122). Atlanta: SBL Press.

Oxford Latin Dictionary. (1968-1982).

Palme, B. (2007). The imperial presence: government and army. In R. S. Bagnall (Ed.), Egypt in the Byzantine world, 300-700 (pp. 244-270). Cambridge: Cambridge University Press.

Palme, B. (2014). Roman litigation: reports of court proceedings. In J. G. Keenan, J. G. Manning, \& U. Yiftach-Firanko (Eds.), Law and legal Practice in Egypt from Alexander to the Arab Conquest (pp. 482-502). Cambridge: Cambridge University Press.

Palme, B. (2016). Eingaben an Militärs im spätantiken Ägypten. In R. Haensch (Ed.), Recht haben und Recht bekommen im Imperium Romanum (The Journal of Juristic Papyrology, Suppl. XXIV; pp. 457-482). Warszawa: Faculty of Law and Administration of the University of Warsaw. 
Pauly, A., Wissowa, G., Kroll, W. et al. (Eds). (1894-1980). Paulys Realencyclopädie der classischen Altertumswissenschaft. Stuttgart: J. B. Metzler.

Pfeiffer, S. (2015). Griechische und lateinische Inschriften zum Ptolemäerreich und zur römischen Provinz Aegyptus (Einführungen und Quellentexte zur Ägyptologie, 9). Berlin: LIT-Verlag.

Pilhofer, P. (2009). Philippi, II: Katalog der Inschriften von Philippi (Wissenschaftliche Untersuchungen zum Neuen Testament, 119). Tübingen: Mohr Seibeck.

Rutherford, I. C. (2012). Travel and Pilgrimage. In C. Riggs (Ed.), The Oxford Handbook of Roman Egypt (pp. 701-716). Oxford - New York: Oxford University Press.

Salway, B. (1994). What's in a Name? A Survey of Roman Onomastic Practice from c. 700 B.C. to A.D. 700. The Journal of Roman Studies, 84, 124-145.

Scharf, R. (1994). Comites und Comitiva Primi Ordinis. Stuttgart: Franz Steiner.

Schulze, W. (1933). Zur Geschichte lateinischer Eigennamen. Berlin: Weidmannsche Buchhandlung.

Skinner, A. (2008). The Early Development of the Senate of Constantinople. Byzantine and Modern Greek Studies, 32(2), 128-148.

Solin, H., \& Salomies, O. (1994). Repertorium nominum gentilium et cognominum Latinorum (2 ${ }^{\text {nd }}$ ed.). Hildesheim: Olms-Weidmann.

Southern, P., \& Dixon, K. R. (1996). The Late Roman Army. New Haven - London: Yale university Press.

Speidel, M. P. (1988). Nubia's Roman garrison. In H. Temporini (Ed.), Aufstieg und Niedergang der Römischen Welt (ANRW). Geschichte und Kultur Roms im Spiegel der neueren Forschung / Rise and decline of the Roman world. Teil 2: Principat. Band 10, 1: Politische Geschichte (Provinzen und Randvölker: Afrika und Ägypten) (pp. 767-798). Berlin - New York: Walter de Gruyter.

The Oxyrhynchus Papyri. (1898-).

Vandorpe, K. (2019). Life portraits: people at work. In Idem (Ed.), A companion to Greco-Roman and late antique Egypt (pp. 269-280). Chichester: John Wiley \& Sons.

Wermelinger, O., Bruggisser, P., Näf, B., \& Roessli, J.-M. (Eds.). (2005). Mauritius und die Thebäische Legion: Akten des internationalen Kolloquiums: Freiburg, Saint-Maurice, Martigny, 17.-20. September 2003. Fribourg: Academic Press Frigourg.

Zawadzki, T. (1969). Un nouveau praefectus castrorum en Égypte et deux obélisques érigés par un centurion. Chronique d'Egypte, 44, 106-117.

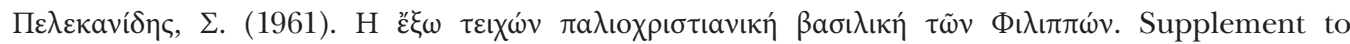

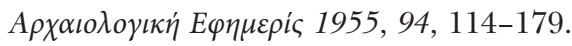

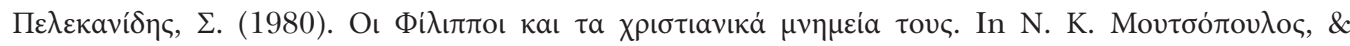

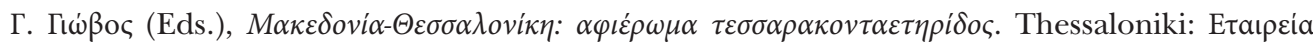

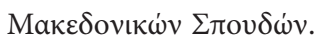


Jiří Honzl

Flavius Mauricius - Glimpses into the Life and Career of Roman Military Official

Mgr. Jiří Honzl / honzlj@ff.cuni.cz

Czech Institute of Egyptology

Charles University, Faculty of Arts

náměstí Jana Palacha 1/2, 11638 Praha 1, Czech Republic 